\title{
Improving students' speaking achievement by using WhatsApp group application in SMP Negeri 4 Natar Lampung Selatan
}

\author{
Nova Regilianti' ${ }^{1}$, Mahpul$^{2}$, Huzairin ${ }^{3}$ \\ English Education Study Program, University of Lampung 1, 2,3 \\ ${ }^{1}$ Correspondence e-mail: \\ novaregiliantii@gmail.com
}

\begin{abstract}
The aim of this study is to know whether there is any improvement of students' speaking achievement after using WhatsApp group application. This is pre-experimental research that involved 1 class in junior high school which included 26 students. The data collecting was gained through pre-test and post-test. Those data were analyzed quantitatively. The result showed that there was significant improvement of students' speaking achievement after using WhatsApp group application. That finding showed that statistically, the average scores of post-test significantly improved than the average scores in the pre-test. It is suggested to use WhatsApp group application to improve students' speaking achievement effectively.
\end{abstract}

Keyword: improving, speaking achievement., WhatsApp group application

\section{INTRODUCTION}

Speaking is the active use of language to express meaning so that other people can understand of them. A speaker needs to find the most appropriate words and the correct grammar to convey meaning accurately and precisely, and needs to organize the discourse so that the listener will understand (Cameron 2001). Speaking is very important in learning a language because as a social creature human needs to interact one and another to express their ideas and thoughts to arrange and persuade others and it is used because someone purposes in learning a language is to be able to communicate the language (Brown 1994). In foreign language teaching and learning, ability to speak is the most essential skill since it is the basic for communication, and it is the most difficult skill (Oradee 2012). According to Nakhalah (2016) there are some factors that cause speaking difficulties, factors that cause difficulty in speaking Students are make a mistake in pronouncing, and many learners lack the necessary of vocabulary. The difficulties in the learning process because motivation and interested in learning process is low. 
Moreover, WhatsApp is an outstanding social media application on mobile phones and very easy to use this application in learning process. The feature of WhatsApp application is appropriate to learning process without face to face. According to Aharony and Zion (2018) WhatsApp is a main mobile instant messaging application that enables users to send and receive real-time, diverse information to individuals and group. Furthermore according to Ta'amneh., (2017) WhatsApp is a mobile application that employs users' existing internet data plan to help them networked and connected with others, it is used for sending and receiving messages, video, picture and audio message. Meanwhile, Kheryadi (2017) stated that there are positive effect on the students progress in learning particular, students show their confidence, independency and enthusiasm and positive attitude towards learning English.

In the previous study, Han and Keskin (2016) who explored that WhatsApp significantly impacted the students' FLA levels and they were able to lessen their anxieties somewhat and therefore they experienced less anxiety after the experience. According to Lauren, Jain, and Abd (2016) who explored that WhatsApp group may also motivate the students to communicate and have discussion on academic matters, since it may bring confidence to student to voice out opinion in the discussion. Based on the previous study above, it is believed that WhatsApp group can improve speaking achievement of the first year students in SMP Negeri 4 Natar Lampung Selatan. The purpose of this study is to know whether there is any significant improvement in students speaking achievement after being taught using WhatsApp group application in SMP Negeri 4 Natar Lampung Selatan?

\section{METHOD}

\section{Participant}

The participants in this research included 26 students of VII B at first grade of SMP Negeri 4 Natar Lampung Selatan in the academic year of 2019/2020. Purposive sampling was selected to gain the population in this research.

\section{Instrument}

The researcher utilized one type of collecting data, the instrument was speaking test.

\section{Data analysis}


In order to get the results of this research, the data then were analyzed and interpreted by means of SPSS version windows 20.0 .

\section{RESULT AND DISCCUSSION}

The result of this research based on the speaking test. The data then were analyzed and interpreted by means of statistical software. In this chapter were explained of the result.

\section{a. Normality test}

The determine of normality test is $(\operatorname{sign}>0,05)$ the sign illustrated that distribution of the data is normal. The normality test can be seen in table 9 .

Table 9. Normality of test

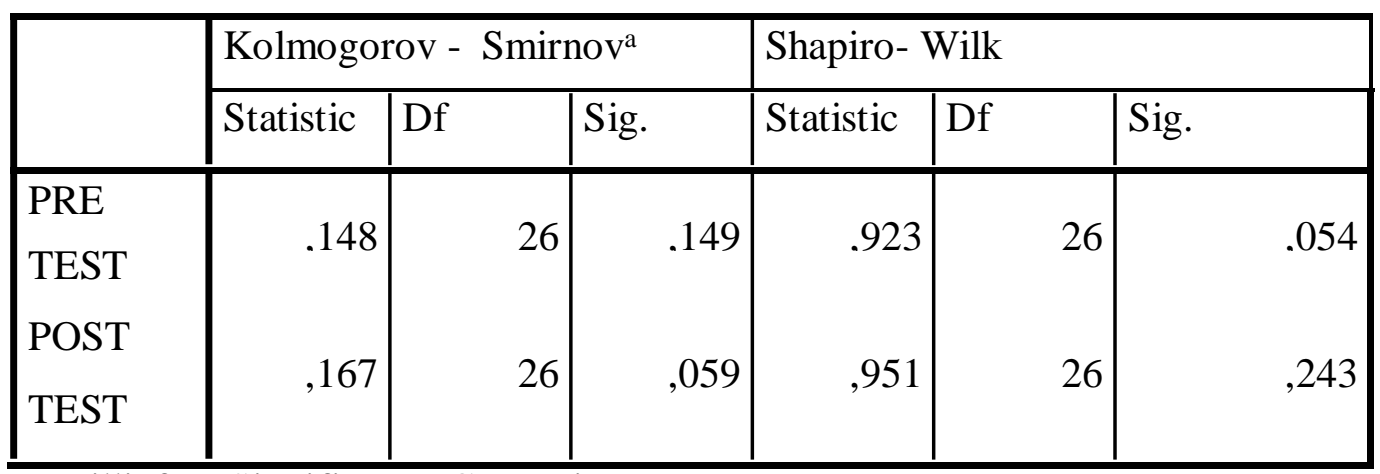

a. Lilliefors Significance Correction

Based on the table above, the data illustrated that the significant value on normality pretest was 0,054 and post-test 0,243 . In this normality test, it could be seen that the result of significant value, it was higher than 0,05 . Furthermore, it can be concludes that the data of pre-test and post test were normal.

\section{b. Paired Sample T- Test}

The paired sample t-test of pre-test and post-test, it can be seen in table 10 .

\section{Paired Samples Test}

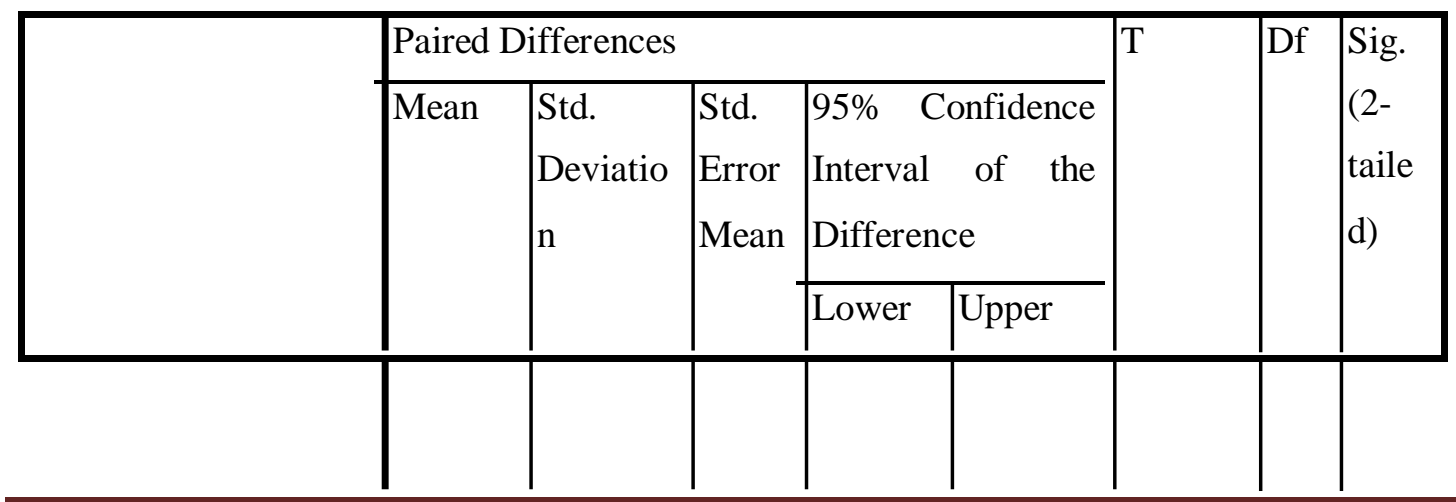




\begin{tabular}{|lllllllll|}
\hline Pair 1 & PRE TEST - & , 17,385 & 4,989 & $-19,400$ & $-15,370$ & $-17,769$ & 25 &, 000 \\
& POST TEST
\end{tabular}

Based on the table above show that the result of the two- tailed significance was 0.00 , it was lower than 0.05 which indicated that the alternative hypothesis was accepted. The data illustrated that there is significant improvement after taught by treatments. Furthermore, it can be conclude that there is significance improvement on students speaking achievement after WhatsApp group application.

\section{DISCCUSSION}

This section discusses about the research findings. The discussion illustrated that whether there was any improvement of the students speaking achievement after being taught by using WhatsApp group application. Based on the result the significant value was 0.00 , it was lower than 0.05. The data illustrated that there is significant improvement after taught by treatments. According to Ta'amneh (2017). Whatsapp is a mobile application that employs users' existing internet data plan to help them networked and connected with others, it used for sending and receiving messages, video, picture and audio massage. Furthermore, According to Aharony and Zion (2018) WhatsApp is a main mobile instant messaging application that enables users to send and receive real-time, diverse information to individuals and group. The researcher decided to give treatment, first treatment was by giving WhatsApp group application students ask about them self introduction in voice note, and the teacher give a feedback to students. The second, students listened the feedback from teacher and record again in voice note, after that they made transcription and discuss in group about a difficult and new word in transcription. Finally, the students make a simple conversation about self introduction and practice.

Based on the result of research finding, the student achievement by using WhatsApp group application is very significant improve in five aspect of speaking. There are some factors that affect improvement students of speaking, the implementation of online class in this research makes students comfortable to ask the teacher about some difficult word and pronounce. The WhatsApp group application is very easy application and they were comfortable and not afraid, when they do not directly face- to-face with the teacher in the class. Furthermore it can be conclude that WhatsApp group application can improve students speaking achievement. It was illustrate that there some aspects of improvement 
in speaking achievement, especially in vocabulary aspect. Since learning in online class the students ware comfortable to ask their problem of pronouncing some word and some vocabulary that they don't known. In this method student listened their speaking in the voice note and it helped students to known their pronouncing.

From the explanation above, it shows that WhatsApp group application is one of the appropriate for teaching English. The pronoun and vocabulary of students was improved after being taught WhatsApp group application. According to the previous research, two of them were conducted by Han and Keskin (2016) explored that WhatsApp significantly impacted the students' FLA levels and they were able to lessen their anxieties somewhat and therefore they experienced less anxiety after the experience. Moreover, according to Lauren, Jain, and Abd (2016) explored that WhatsApp group may also motivate the students to communicate and have discussion on academic matters, since it may bring confidence to student to voice out opinion in the discussion. Therefore, based on the explanation above it can be seen that community language learning can improve students speaking achievement.

\section{CONCLUSSION}

The research then made conclusion that there is a significant improvement on students speaking achievement after using WhatsApp group application in grammar, pronunciation, vocabulary, fluency, and accuracy. It can be seen from the result of this research, the significant values are all less than 0.05. Furthermore, it can be concluded that WhatsApp group application improved student speaking achievement.

\section{SUGGESTIONS}

Regarding to this conclusion, the researcher suggested for English teacher first, English language is difficult, teacher have to make the students interested, and make student active and not afraid in the class. It is recommended to use WhatsApp group application. Second, the teacher is suggested to use WhatsApp group application to teach in the class, because students need to learn in the group to communicate with other students and make them comfortable to ask a teacher without face to face in the class. Furthermore, it was suggested for further researchers, this study is conducted in first grade of junior high school, moreover the further researchers can try to conduct in other level in the senior high school. It is better if further researchers use two class in the research such as experimental class and control class in order to see some different 
achievement of students. Since this research discusses about improvement of students, it is better if further researcher also discuss about perception of students.

\section{REFERENCES}

Ahrony, N., \& Zion, A. (2018). Effect of WhatsApp use working memory performance among youth. Journal of education computing research, Vol. 57 (1), 226-245.

Brown, H. D. (1994). Teaching by principles. Englewood cliffs ,Nj; Prentice Hall. Cameron, L. (2001). Teaching languages to young learners. Edinburg: Cambridge University Press.

Han, T., \& Keskin, F. (2016). Using a mobile application (WhatsApp) to reduce efl speaking anxiety. Gist Education And Learning research Journal, (12),29-50.

Kheryadi, K. (2017). The implementation of "WhatsApp" as a media of English language teaching. Loquen: English studies journal, 10 (2), 1-14.

Luaran, E. Jain, J. And Abd, R.N. (2016). The use of whatsapp group in class-related information sharing through academic discussion. International Journal on ELearning and Higher Education, Vol. 4, 176-194.

Nakhhalah, A.M.M.A. (2016). Problems and difficulties of speaking that encounter English language students at al quads open university. Journal of Humanities and Social Science Invention, Vol. 5, 96-101.

Orade. T. (2012). Developing speaking skills using three communicative activities(discussion, problem-solving, and role playing. Journal of Social Science And Humanity, Vol. 2, 164.

Ta'amneh, M.A.A.A.(2017). The effect of using whatsapp massager in learning English language among university students. International Research In Education, 5(1). 